\title{
EFFECTS OF PREHARVEST TREATMENTS ON YIELD AND CHEMICAL COMPOSITION OF TOMATO
}

\author{
M. MEAZA, T. SEYOUM and K. WOLDETSADIK ${ }^{1}$ \\ Alemaya University, College of Agriculture, Department of Food Science and Postharvest Technology, \\ P. O. Box 131, Alemaya, Ethiopia \\ ${ }^{1}$ Alemeya University, College of Agriculture, Department of Plant Science, P. O. Box 138, \\ Dire Dawa, Ethiopia
}

(Received 24 March, 2006; accepted 27 January, 2007)

\begin{abstract}
Postharvest losses in tomato (Lycopersicon esculentum L.) are among others, the prime factor affecting the quantity and quality of tomato fruits in the market. Options to avert these losses are limited, and thus the need to design research studies that are geared to developing such strategies. A field experiment was therefore conducted to study effects of preharvest treatment of ComCat ${ }^{\circledR}$ spray, manure, NP fertilisation and the combinations of ComCat ${ }^{\circledR}$ with the two forms of fertilisation and the control on yield and quality of tomato in semiarid climate in eastern part of Ethiopia. The experiment was conducted using randomised complete block design with 3 replications. Data were collected from two centeral rows of treatment plots to assess vegetative growth, yield and the chemical composition of fruits at harvest. The result showed that the use of ComCat ${ }^{\circledR}$ and its combination with manure gave the highest total yield 58.53 tha $^{-1}$ and 55.77 tha $^{-1}$ of which $94 \%$ and $93 \%$ were marketable and total yield, respectively. By using manure and NP fertiliser it was observed that both marketable and total yield was not significantly influenced. The control tomato plants were found to give higher total and marketable yield on comparison with the preharvest ComCat ${ }^{\circledR}+$ NP treatment. The chemical qualities of tomatoes were improved by preharvest ComCat ${ }^{\circledR}$, ComCat ${ }^{\circledR}+$ manure and ComCat ${ }^{\circledR}=\mathrm{NP}$ treatments. Based on the varied performance of the treatements imposed, adoption of a particular teatment will depend on a specific recommendation dormain.
\end{abstract}

Key Words: Ethiopia, fertilisation, Lycopersicon esculentum, marketable yield

\section{RÉSUMÉ}

Les pertes après récolte de la tomate (Lycopersicon esculentum L.) sont parmi les autres, le facteur primordial affectant la quantité et la qualité de fruits de tomate sur le marché. Les options pour minimiser ces pertes sont limitées, et ainsi le besoin de concevoir les études de recherche qui sont adaptées au développement de telles stratégies. Une expérience de champ a été donc dirigée pour étudier des effets de traitement de pré récolte Comcat@ spray, le fumier, la fertilisation de NP et les combinaisons de Comcat@ avec les deux formes de fertilisation et le contrôle sur le rendement et la qualité de tomate dans le climat à demi aride de l'est de l'Ethiopie. L'expérience a été conduite sur de blocs complètement aléatoires avec 3 réplications. Les données ont été recueillies sur deux rangs centraux de terrains de traitement pour évaluer la croissance végétale, le rendement et la composition chimique de fruits à la moisson. Le résultat a montré que l'usage de Comcat@ et sa combinaison avec le fumier a donné le plus haut rendement total 58,53 tha $^{-1}$ et 55.77 tha $^{-1}$ dont $94 \%$ et $93 \%$ était le rendement vendable et total, respectivement. En utilisant l'engrais de fumier et NP il a été observé que le rendement vendable et total n’a pas été significativement influencé. Les plantes de tomate de contrôle ont donné le plus haut rendement total et vendable par rapport pré récolte + le traitement de NP. Les qualités chimiques de tomates ont 
été améliorées par la combinaison pré récolte + le fumier et = les traitements de NP. Sur base de la performance des divers traitements imposés, l'adoption d'un traitement particulier dépendra de recommandations dans un domaine spécifique.

Mots Clés: L’Ethiopie, la fertilisation, Lycopersicon esculentum, le rendement vendable

\section{INTRODUCTION}

Post harvest qualities of tomatoes partly depend upon preharvest factors such as cultural practices, genetic and environmental conditions (Hobson, 1964; Pretorious et al., 2003). Cultural practices such as nutrient, water supply and harvesting methods quality of tomato before and after harvest (Fischer and Richter, 1986). Similarly, natural plants can also be used for purposes of protecting the quality of fruits (Hüster, 2001, Schenable et al., 2001). For example, ComCat ${ }^{\circledR}$ was developed as a natural product and has plant strengthening properties and the ability to improve growth and yield in different agricultural crops. ComCat ${ }^{\circledR}$ is natural biocatalysts, which is extracted from seeds of plants and mainly consists of aminoavids, gibberellin, kitenins, auxin (indole-3-acitic acid), brassinosteroids, natural metabolites, pathogenresistance-proteins with defence reactions, terpenoids, flavonoids, vitamins, inhibitors, other signal molecules, biocatalysts and cofactors (Hüster, 2001; Schenable et al., 2001).

Quality management starts in the field and continues until produce reaches the end user. The response of fruit and vegetables during storage to post-harvest factors also in part depends on pre-harvest practices such as use of natural plant exteract such as ComCat ${ }^{\circledR}$, fertilisers, manure and environmental factors. Understanding and managing the various roles that preharvest factors play on quality is very important in order to achieve maximum harvest and post harvest quality for any crop. Mostly, preharvest conditions are of overriding importance in determining storage behavior. In some cases, their effects can be greater than the effects of adjustment of storage environment. To date, preharvest treatment recommendations for fruits and vegetables have been established primarily to enhance productivity, and not as diagnostics for good quality, nutritive value and optimum shelf life. As a result, the need for the integration of pre and post harvest treatment for the improvement of shelf life remains critical. A study was therefore designed to investigate the effect of farmyard manure, NP fertilisers and ComCat ${ }^{\circledR}$ on the growth, yield and chemical compositions of tomatoes at harvest.

\section{MATERIALS AND METHODS}

Site description. A field experiment was conducted at Alemaya University Farm located in Dire Dawa Ethiopia, during the growing season of 2004/2005. The research site is located at an altitude of $1197 \mathrm{~m}$ above sea level and lies at 96' $\mathrm{N}$ and $41^{\circ} 8$ ' $E$. The station lies in the semi-arid belt of the eastern rift valley escarpment with mean annual rainfall of $520 \mathrm{~mm}$ and mean maximum and minimum temperatures ranging from $28.1^{\circ} \mathrm{C}$ to $34.6^{\circ} \mathrm{C}$ and $14.5^{\circ} \mathrm{C}$ to $21.6^{\circ} \mathrm{C}$, respectively (Belay, 2002).

Experimental materials and design. Fresh market tomato variety, Marglobe, was raised in glass house for about two weeks pricked and grown on nursery bed for another three weeks. The seedlings were transplated to plots consisting of six rows $0.75 \mathrm{~m}$ apart, with 90 plants per plot and spaced $0.5 \mathrm{~m}$ apart in the row. The spacing between plots in each replication and adjacent replications was 2 meter and 1.5 meter, respectively.

Field treatments consisted of recommended rate of NP fertilisation (92 kg of P2O5 and $95 \mathrm{~kg} \mathrm{~N}$ per ha), farmyard manure (20 tons per ha), ComCat ${ }^{\circledR}$ (100 g per ha), NP manure each in combination with ComCat ${ }^{\circledR}$. The source for NP fertiliser was diammonium phosphate (DAP) and urea. Manure, DAP and half of the nitrogen fertiliser were incorporated to the experimental plots before planting while the rest of the nitrogen was applied two weeks after the establishment of seedlings. ComCat ${ }^{\circledR}$ was applied at $100 \mathrm{gha}^{-1}$ in 
$350 \mathrm{~L}$ and sprayed twice during the growth period. First spray was done prior to transplanting of seedlings while the second was carried out before flowering as recommended by Huster (2001). Other agronomic practices (weeding, cultivation, irrigation, staking, etc.) were applied uniformly to all plots following standard agronomic recommendation for tomato cultivation. Plots were irrigated every other day for the first two weeks and then at weekly interval. Fungicides (Ridomil + MZ 63\% and Mancozeb $3.5 \mathrm{~kg} \mathrm{ha}^{-1}$ ) were applied to control leaf disease and cypermethrin (100 g.a.i ha ${ }^{-1}$ ) was used to control insect pests. The pesticides were sprayed at seven days interval from transplanting to 20 days before first harvest. The experiment was laid out in randomised complete block design with three replications.

Data collection. Data including growth parameters, yield attributes, fruit characteristics and chemical analysis were recorded. For growth parameters, assessment was made from the central four rows of ten randomly sampled plants per plot. The total numbers of leaves (LN) counted at weekly intervals starting from crop emergence till $50 \%$ of the plants got bloomed. The heights $(\mathrm{cm})$ of plants $(\mathrm{PH})$ measured from the ground level to the highest point at blooming stage. The number of primary and secondary branches (NBP) of each plant was recorded. Mean height $(\mathrm{cm})$ of primary lateral shoots of each plant (HBP) of each treatment at blooming stage was recorded. The average length of three leaves $(\mathrm{cm})(\mathrm{LL})$ from the upper, middle and lower part of the plant was measured at blooming stage. The average size of three leaves $(\mathrm{cm})(\mathrm{LW})$ at the widest point form the upper, middle and lower part of the plant was measured at blooming stage. Days to $50 \%$ flowering (DF) was recorded when approximately $50 \%$ of the flower clusters on the plant had some flowers that were in bloom. Days to maturity (DM) was recorded when approximately $70 \%$ of the plants had attained physiological maturity. Number of cluster per plant (CP) was counted at physiological maturity. Number of fruits per cluster (FC) was counted at physiological maturity.
Tomato fruits, which were handicaped at the green mature, were selected from each treatment of the middle for rows. Harvesting was carried out once a week. The total fruit yield, marketable fruit yield and fruit number per plant, were determined immediately after each harvest while fruit volume, fruit size and juice content were determined at the third harvest. Harvesting for yield comparison was done eight times based on a weekly interval. Dropped fruits were not considered.

Total number/weight of fruits is the sum total number/weight of fruits of successive harvests. Fruits were categorised as marketable and unmarketable fruits of each treatment. Fruits, which were cracked, damaged by insect, diseases, birds and sunburn, etc. were considered as unmarketable while fruits, which were free of damage, were considered as marketable. The fruit size was considered to be the diagonal section of the fruit measured by caliper.

Ten randomly selected fruits ten plants in a plot were taken and floated in a water jar and their displacement was recorded. Average fruit volume was taken by subtracting the initial water level in the jar from the final and by the number of fruit immersed.

The juice content of tomato was extracted using a juice extractor (Kenwood). The intact tomato weight was recorded prior to juice extraction. After extraction, extracted juice was measured using a graduated glass cylinder and expressed in milliliter of juice per kilogram of fruit weight $\left(\mathrm{ml} \mathrm{kg}^{-1}\right)$.

\section{Chemical analysis}

Total Soluble Solids (TSS). The TSS was determined using an aliquout of juice extracted using a juice extractor. An Atago N, hand refractometer with a range of 0 to $32{ }^{\circ} \mathrm{Brix}$ and resolutions of 0.2 Brix was used to determine TSS by placing 1 to 2 drops of clear juice on the prism.

Ascorbic Acid Analysis (AA). The ascorbic acid content was determined by the 2, 6dichlorophenol indophenol method (AOAC, 1970). An aliquot of $10 \mathrm{ml}$ tomato juice extract 
was diluted to $50 \mathrm{ml}$ with 3 percent metaphosphoric acid in a $50 \mathrm{ml}$ volumetric flask.

The aliquot was then centrifuged for 15 minutes and titrated with the standard dye to a pink and point (persisting for 15 second). The ascorbic acid content was calculated from the titration value, dye factor, dilution and volume of the sample.

pH and Titratable Acidity (TA). Tomato juice was extracted from the sample with a juice extractor and clear juice was used for the analysis of TA. The titrable acidity expressed as percent citric acid, was obtained by titrating $10 \mathrm{ml}$ of juice to $\mathrm{pH} 8.2$ with $0.1 \mathrm{~N} \mathrm{NaOH}$. The $\mathrm{pH}$ value of the juice was measured with a $\mathrm{pH}$ meter.

Sugar analysis. Reducing and total sugars were estimated by using the techniques of Seyoum (2002). Liquidized fresh tomato tissue (10 g) was added to $15 \mathrm{ml}$ of 80 percent ethanol, mixed and heated in boiling water bath for sufficient time until the ethanol odor wet off. After extraction, $1 \mathrm{ml}$ of saturated $\mathrm{Pb}\left(\mathrm{CH}_{3} \mathrm{COO}\right)_{2}$ and $1.5 \mathrm{ml}$ of $\mathrm{NaHPO}_{4}$ were added and the contents were mixed by gentle shaking. After filtration, the extract was made up to $50 \mathrm{ml}$ with distilled water. An aliquot of $1 \mathrm{ml}$ extract was diluted to $25 \mathrm{ml}$ with 1 $\mathrm{ml}$ copper reagent in a test tube and heated for 20 minutes in a boiling water bath. After heating, the contents were cooled under running tap water without shaking. Arsenomolybdate color reagent $(1 \mathrm{ml})$ was added, mixed, made up to $10 \mathrm{ml}$ with distilled water and left for about 10 minutes to allow color development, after which the absorbance was determined by Jenway model 6100 spectrophotometer at $540 \mathrm{~nm}$. For total sugar determination, sugar was first hydrolyzed with INHCI by heating at $70^{\circ} \mathrm{C}$ for 30 minutes. After hydrolysis total sugar was determined following the same procedure employed for the reducing sugar. A blank was prepared using distilled water.

Statistical procedures. Significant differences between the treatments were determined using analysis of variance (ANOVA) for factorial experiment in RCBD using MSTAT-C software (MSTAT, Michigan Univ. East Lansing) and the treatment mean were separated using the least significant difference (LSD).

\section{RESULTS AND DISCUSSION}

Growth of plant. One month after transplanting, there was a relatively poor stand of seedlings in manure, ComCat ${ }^{\circledR}+$ manure and control plots while application of NP fertiliser enhanced early growth. The reason for poor stand of seedlings could be attributed to competition of decaying microroganisms for nutrients and slow availability of nutrient during early stage. One possible reason for the vigorous initial growth in NP treated plants could be the addition of NP fertiliser that dissolves rapidly to meet the immediate nutrient demand of the plant. Initial growth in terms of leaf number was significantly $(\mathrm{P}<0.01)$ high for ComCat ${ }^{\circledR}+\mathrm{NP}$ and NP treatments (Table 1). For the leaf counting, well established and strong seedlings were observed in ComCat ${ }^{\circledR}$ treated tomato plants. This could be due to the ability of ComCat ${ }^{\circledR}$ to enhance better root development that could enable the plant absorb water and nutrients (Hüster, 2001; Schnable et al., 2001) and resistance to disease and environmental stress (Pretorius et al., 2003). Hüster (2001) and Schnable et al. (2001) also reported the role of ComCat ${ }^{\circledR}$ in promoting root development.

The preharvest treatments significant $(\mathrm{P}<$ 0.01) affected number of leaves (Table 1 ). During the second count, the number of leaves of tomato plants subjected to NP, ComCat ${ }^{\circledR}+\mathrm{NP}$ and ComCat ${ }^{\circledR}+$ manure treatments were significantly $(\mathrm{P}<0.01)$ higher compared with the number of leaves of tomato plants subjected to manure and control manure treatments.

Manure application resulted in significantly $(\mathrm{P}<0.05)$ longer tomato plants compared to the height of the control tomatoes. This might be because of the ability of manure in creating suitable plant growing environment by improving moisture and nutrient status of the soil. Hader (1986) reported the organic fertilisers compensate both the deficit and the excess of elements in the soil, which can take place with mineral fertilisation. ComCat ${ }^{\circledR}$ had no significant effect on the plant height when compared to the control plants. Similar findings were reported by Hüster (2001). There was no difference in plant height among the manure, ComCat ${ }^{\circledR}+$ manure,ComCat ${ }^{\circledR}+\mathrm{NP}$ and ComCat ${ }^{\circledR}$ treatments. However, manure treated tomato plants were relatively tallest 
TABLE 1. Weekly (W) count of tomato plant leaf number starting from establishment

\begin{tabular}{|c|c|c|c|c|c|c|c|}
\hline Treatment & W1 & W2 & W3 & W4 & W5 & W6 & W7 \\
\hline ComCat $\AA$ & $36.90^{\mathrm{a}}$ & $88.80^{\mathrm{bc}}$ & $102.07^{\mathrm{bcd}}$ & $205.70^{\mathrm{b}}$ & $288.90^{\mathrm{ab}}$ & $355.67^{c}$ & \\
\hline Manure & -1 & $69.57^{\text {cd }}$ & $83.00^{\text {cd }}$ & $197.73^{b}$ & $246.60^{b}$ & $326.80^{\mathrm{bc}}$ & $340.77^{c}$ \\
\hline Inorganic fertiliser & $33.63^{a}$ & $96.40^{\mathrm{ab}}$ & $110.77^{\mathrm{bc}}$ & $235.27^{\mathrm{ab}}$ & $338.03^{a}$ & $384.63^{\mathrm{ab}}$ & $434.33^{b}$ \\
\hline ComCat $\AA$ + Manure & -1 & $100.50^{\mathrm{ab}}$ & $133.00^{b}$ & 241.63ab & $293.03^{\mathrm{ab}}$ & $326.80^{\mathrm{bc}}$ & $356.97^{c}$ \\
\hline ComCat ${ }^{\circledR}+$ inorganic & $42.13^{a}$ & $115.57^{\mathrm{a}}$ & $216.87^{a}$ & $282.67^{\mathrm{a}}$ & $313.57^{\mathrm{ab}}$ & $452.70^{\mathrm{a}}$ & $571.50^{\mathrm{a}}$ \\
\hline Control & -1 & $50.80^{d}$ & $65.70^{d}$ & $107.37^{c}$ & $251.83^{b}$ & $2725.23^{c}$ & $298.40^{c}$ \\
\hline CV (\%) & 32.4 & 12.32 & 18.83 & 14.73 & 13.92 & 14.03 & 9.62 \\
\hline LSD & 11.07 & 19.48 & 40.62 & 56.73 & 73.09 & 86.32 & 68.75 \\
\hline $\mathrm{SE} \pm$ & 3.513 & 6.1832 & 12.8896 & 18.0049 & 23.1944 & 27.3947 & 21.8189 \\
\hline Significance ${ }^{2}$ & * & ** & $\star *$ & ** & NS & * & $\star *$ \\
\hline
\end{tabular}

${ }^{1}$ : Leaf count was not done since plants of respective treatments did not establish well. ${ }^{2}$ : Level of significance where NS, * and ** stands for significance level at $p<0.01$ and 0.05 , respectively

followed by ComCat ${ }^{\circledR}+$ manure,ComCat ${ }^{\circledR}+\mathrm{NP}$ and ComCat ${ }^{\circledR}$ treated tomato plants. Application of NP and ComCat ${ }^{\circledR}+$ NP fetiliser resulted in significantly $(\mathrm{P}<0.01)$ higher number of primary lateral branches per plant compared to ComCat ${ }^{\circledR}$, ComCat ${ }^{\circledR}+$ manure, manure and control tomato plants. The application of $\mathrm{ComCat}{ }^{\circledR}$, manure and their combinations had no significant $(\mathrm{P}<0.01)$ difference on the number of primary lateral shoot. Although vegetative growth (plant height and number of lateral shoots) was enhanced by the application of inorganic fetiliser and ComCat ${ }^{\circledR}+$ NP treatments, ComCat ${ }^{\circledR}$ had no effect on the vegetative growth but the branches were observed to be stronger. This might indicate that nitrogen stimulates excessive vine growth while ComCat ${ }^{\circledR}$ does not have such an effect. Hüster (2001) reported the simulating effect of nitrogen on vegetative growth of beet root and cauliflower whereas such property is absent in ComCat ${ }^{\circledR}$ treated plants.

Leaves were significantly $(\mathrm{P}<0.01)$ longer from ComCat $₫$ treated tomato plants compared to manure, NP, ComCat ${ }^{\circledR}+\mathrm{NP}$, ComCat ${ }^{\circledR}+$ manure and control tomato plants (Table 2). Similarly, the application of manure, NP and ComCat ${ }^{\circledR}+$ manure resulted in significantly $(\mathrm{p}<$ $0.01)$ longer leaves when compared to ComCat ${ }^{\circledR}$ + NP and the control tomato plants.ComCat ${ }^{\circledR}$ significantly ( $\mathrm{p}<0.01$ ) increased both leaf length and width compared with the rest of the treatments. As a result, large and broad leaves were observed in ComCat ${ }^{\circledR}$ treated tomato plants. In addition, the leaves were deep green in colour which is in agreement with the previous findings by Pretorious et al. (2003). The vegetative growth of tomato in terms of the height of primary shoots, number and height of secondary shoots did not show significant variation among the treatments tested.

Application of ComCat ${ }^{\circledR}+\mathrm{NP}$ treatment took significantly longer time (60 days) for 50 percent of flower clusters to bloom compared to the rest of the treatments (Table 2). Treatments that received NP fertiliser application took significantly $(p<0.01)$ longer time (52 days) to bloom compared to ComCat ${ }^{\circledR}$, manure and control tomatoes. This seems to indicate that excess nitrogen resulted in excessive lateral shoot growth that probably have impaired reproductive development by decreasing sink strength of inflorescence relative to vegetative tissues. This result is in agreement with the findings of Dieleman and Heuvelink (1992) who reported delayed flowering due to over fertilisation. ComCat ${ }^{\circledR}$ ( 41 days), manure (42 days), ComCat ${ }^{\circledR}$ + manure (47 days) and control tomatoes resulted in early flowering.

ComCat ${ }^{\circledR}+\mathrm{NP}$ took significanlty $(\mathrm{p}<0.05)$ longer time (91 days) for 70 percent of the fruits to get matured compared to ComCat ${ }^{\circledR}$. Manure and control tomato plants (Table 2). Similarly, NP 
treatment took significantly $(\mathrm{P}<0.05)$ longer time (90 days) compared to ComCat ${ }^{\circledR}$ and control tomato plants.

Yield and fruit characters. The results of preharvest treatments on yield and yield related traits of tomato are presented in Table 3. ComCat ${ }^{\circledR}$ treated tomato plants had significantly $(\mathrm{P}<0.01)$ higher number of clusters per plant (17.3) compared with manure (14.7), ComCat ${ }^{\circledR}+\mathrm{NP}$ (13.3) and control (9.6) tomatoes. Plants subjected to NP and ComCat ${ }^{\circledR}+$ manure applications had statistically similar cluster number per plant with that of ComCat ${ }^{\circledR}$ treated tomato plants. ComCat ${ }^{\circledR}$ + manure treatment had significantly $(\mathrm{P}<0.05)$ higher number of fruit per cluster compared to ComCat ${ }^{\circledR}+\mathrm{NP}$ and control tomatoes. The maximum cluster number in ComCat ${ }^{\circledR}$ treated

TABLE 2. Effect of ComCat ${ }^{\circledR}$, manure, nitrogen, and phosphorous, and their combinations on some of the growth components of fresh market Marglobe tomato cultivar

\begin{tabular}{|c|c|c|c|c|c|c|c|c|c|}
\hline Treatment & $\begin{array}{l}\amalg \\
(\mathrm{cm})\end{array}$ & $\begin{array}{l}\text { LW } \\
(\mathrm{cm})\end{array}$ & $\begin{array}{l}\text { PLH } \\
(\mathrm{cm})\end{array}$ & $\begin{array}{l}\text { LSN } \\
(\mathrm{cm})\end{array}$ & $\begin{array}{l}\text { LSH } \\
(\mathrm{cm})\end{array}$ & $\begin{array}{l}\text { SLSN } \\
(\mathrm{cm})\end{array}$ & $\begin{array}{l}\text { SLSH } \\
(\mathrm{cm})\end{array}$ & $\begin{array}{l}\text { DYF } \\
\text { (days) }\end{array}$ & $\begin{array}{l}\text { DYM } \\
\text { (days) }\end{array}$ \\
\hline$C C$ & $5.42^{\mathrm{a}}$ & $12.48^{a}$ & $52.47^{a b}$ & $5.86^{b}$ & $20.52 a$ & $2.57^{\mathrm{a}}$ & $7.20^{\mathrm{a}}$ & $40.67^{c}$ & $76.33^{c}$ \\
\hline$M$ & $4.78^{b}$ & $11.42^{2 \mathrm{ab}}$ & $59.70^{a}$ & $6.00^{\mathrm{b}}$ & $24.88 a$ & $2.27^{\mathrm{a}}$ & $7.97^{\mathrm{a}}$ & $41.67^{c}$ & $78.33 b^{c}$ \\
\hline NP & $4.53^{b}$ & $10.70^{b c}$ & $49.90^{\mathrm{ab}}$ & $7.63^{\mathrm{a}}$ & $25.50^{\mathrm{a}}$ & $2.37^{\mathrm{a}}$ & $11.86^{a}$ & $89.67^{a b}$ & \\
\hline$C C+M$ & $4.57^{\mathrm{b}}$ & $11.24^{b}$ & $57.13^{a b}$ & $6.03^{b}$ & $23 .{ }^{12 a}$ & $2.70^{a}$ & $10.75^{a}$ & $47.00^{\mathrm{b}} \mathrm{C}$ & $79.33^{\mathrm{abc}}$ \\
\hline$C C+N P$ & $3.41^{c}$ & $9.14^{d}$ & $54.80^{\mathrm{ab}}$ & $8.43^{\mathrm{a}}$ & $21.85^{a}$ & $3.34^{a}$ & $9.18^{a}$ & $60.33^{a}$ & $91.00^{a}$ \\
\hline C & $3.54^{c}$ & $9.87^{\mathrm{cd}}$ & $45.17^{b}$ & $4.93^{b}$ & $21.75^{a}$ & $3.47^{a}$ & $10.44 a$ & $40.67^{c}$ & $75.67^{c}$ \\
\hline Significance & ** & $* *$ & * & ** & ns & ns & ns & ** & * \\
\hline $\mathrm{SE} \pm$ & 0.176 & 0.391 & 4.0775 & 0.388 & 3.373 & 0.741 & 1.939 & 2.203 & 3.7693 \\
\hline
\end{tabular}

Means within columns not sharing the same letter as significantly different, ${ }^{* \star}$ and ${ }^{*}$ indicates significant difference at $p<0.01$ and 0.05 by $L S D$, respectively. $N s=$ non-significant, $L L=$ leaf length, $L W=$ leaf width, $\quad P L H=$ Plant height, $L S N=$ Lateral shoot number, $\mathrm{LSH}=$ lateral shoot height, $\mathrm{SLSN}=$ secondary lateral shoot number, $\mathrm{SLSH}=$ secondary lateral shoot height, $\mathrm{DYF}=$ days to flowering, $\mathrm{DYM}=$ days to maturity, $\mathrm{CC}=\mathrm{ComCat}, \mathrm{M}=$ manure, $\mathrm{NP}=$ nitrogen and phosphorous, $\mathrm{CC}+\mathrm{M}$ $=$ ComCat + Manure, $\mathrm{CC}+\mathrm{NP}=\mathrm{ComCat}+$ nitrogen and phosphorous, $\mathrm{C}=$ control

TABLE 3. The effect of ComCat ${ }^{\circledR}$, manure, nitrogen and phosphorous fertiliser on the yield components of fresh market Marglobe tomato cultivar

\begin{tabular}{llllll}
\hline Treatment & $\begin{array}{l}\mathrm{CN} \\
(\mathrm{No})\end{array}$ & $\begin{array}{l}\mathrm{F} / \mathrm{CL} \\
(\mathrm{No})\end{array}$ & $\begin{array}{l}\mathrm{FRS} \\
\left(\mathrm{Cm}^{3}\right)\end{array}$ & $\begin{array}{l}\mathrm{FV} \\
\left(\mathrm{cm}^{3}\right)\end{array}$ & $\begin{array}{l}\mathrm{FJ} \\
\left(\mathrm{ml} \mathrm{kg}^{-1}\right)\end{array}$ \\
\hline $\mathrm{CC}$ & $17.30^{\mathrm{a}}$ & $2.89^{\mathrm{ab}}$ & $7.61^{\mathrm{a}}$ & $0.26^{\mathrm{a}}$ & $689.50^{\mathrm{bcd}}$ \\
$\mathrm{M}$ & $14.70^{\mathrm{b}} \mathrm{C}$ & $2.26^{\mathrm{cd}}$ & $7.03^{\mathrm{ab}}$ & $0.23^{\mathrm{a}}$ & $963.90^{\mathrm{a}}$ \\
$\mathrm{NP}$ & $16.50^{\mathrm{ab}}$ & $3.32^{\mathrm{a}}$ & $6.39^{\mathrm{bc}}$ & $0.14^{\mathrm{a}}$ & $864.70^{\mathrm{ab}}$ \\
$\mathrm{CC}+\mathrm{M}$ & $16.37^{\mathrm{ab}}$ & $2.70^{\mathrm{bc}}$ & $7.33^{\mathrm{ab}}$ & $0.23^{\mathrm{a}}$ & $624.30^{\text {cd }}$ \\
$\mathrm{CC}+\mathrm{NP}$ & $13.27^{\mathrm{c}}$ & $2.70^{\mathrm{bc}}$ & $7.33^{\mathrm{ab}}$ & $0.23^{\mathrm{a}}$ & $624.30^{\text {cd }}$ \\
Control & $9.57^{\mathrm{d}}$ & $2.23^{\mathrm{d}}$ & $6.78 \mathrm{a}^{\mathrm{bc}}$ & $0.153^{\mathrm{a}}$ & $770.10^{\mathrm{abc}}$ \\
Significance & $* *$ & $*$ & $*$ & $*$ & 8 \\
SE \pm & 0.6472 & 0.1407 & 0.3085 & 0.0108 & 30.9978 \\
\hline
\end{tabular}

Means within column not sharing common lettering different at $P<0.01$ and $p<0.05$ where * and ** indicates $p<0.01$ and 0.05 , respectively by $\mathrm{LSD} ; \mathrm{F} / \mathrm{CL}=$ Fruit per cluster, $\mathrm{FV}=$ fruit volume, $\mathrm{FJ}=$ Juice, $\mathrm{CN}=$ Cluster number, $\mathrm{FRS}=$ fruit size, $\mathrm{CC}=$ ComCat, $\mathrm{M}=$ Manure, $\mathrm{NP}=$ nitrogen and phosphorous, $\mathrm{CC}+\mathrm{M}=\mathrm{ComCat}+$ manure, $\mathrm{CC}+\mathrm{NP}=\mathrm{Comcat}+$ nitrogen and phosphorous, $\mathrm{C}=$ Control 
plants was probably due to the activity of ComCat ${ }^{\circledR}$ in accelerating flower bud formation and increasing plant self defence mechanisms and resistance (Hüster, 2001; Pretorious et al., 2003). ComCat ${ }^{\circledR}$ improves better development that enables plants to adapt better and utlise the available soil waster as well as nutrient. ComCat ${ }^{\circledR}$ treatment significantly $(\mathrm{P}<0.05)$ increased fruit size compared to NP and ComCat ${ }^{\circledR}+\mathrm{NP}$ treated tomato plants. Manure and ComCat ${ }^{\circledR}+$ manure tomato plants significantly $(\mathrm{P}<0.05)$ increased fruit size than ComCat ${ }^{\circledR}+\mathrm{NP}$ treated tomato plants. Lower fruit size was obtained from tomatoes treated with NP, ComCat ${ }^{\circledR}+\mathrm{NP}$ and control treatments. This indicates that the addition of NP resulted in significant $(\mathrm{P}<0.05)$ reduction in fruit size. This may have been due to higher nitrogen levels promoting the development of more clusters per plant, which resulted in greater fruit load per plant and smaller fruit size (Brecht et al., 1976).

ComCat ${ }^{\circledR}$ stimulates higher sugar production which is the building blocks for cellulose and fruiting bodies. One of the physical expressions of these response is better flowering and greater fruit biomass that can lead to yield increases in vegetables and fruit (Hüster, 2001).

An overview of total, marketable and unmarketable fruit number and yield response of tomato plant to different preharvest treatment is presented in Table 4. ComCat ${ }^{\circledR}$ treated tomatoes had significantly $(\mathrm{P}<0.05)$ higher total fruit yield compared to NP, ComCat ${ }^{\circledR}+\mathrm{NP}$ and control tomatoes. Similarly, ComCat ${ }^{\circledR}+$ manure treated tomatoes had significantly $(\mathrm{P}<0.05)$ higher total fruit yield than ComCat ${ }^{\circledR}+\mathrm{NP}$ and control treatments.

The total and marketable fruit number obtained from ComCat ${ }^{\circledR}+$ NP treated tomatoes was significantly $(\mathrm{P}<0.05)$ lower compared to other treatments. The total and marketable fruit number obtained from tomatoes grown using manure and NP fertilisers were not significant ( $\mathrm{P}$ $<0.05$ ) as compared to the number and yield of unmarketable fruit was obtained from NP fertilised tomatoes, followed by ComCat ${ }^{\circledR}+\mathrm{NP}$ treated tomatoes.

The higher marketable fruit yield of tomato treated with ComCat ${ }^{\circledR}$ compared to NP, manure, ComCat ${ }^{\circledR}+\mathrm{NP}$ and control tomatoes, is in agreement with the findings of Schnable et al. (2001) who reported the yield increase by 16-19\% due to ComCat ${ }^{\circledR}$ treatment in difference crops including tomato. In addition, Hüster (2001) reported that ComCat ${ }^{\circledR}$ reduced the occurrence of disease by more than $40 \%$ which could be in part the reason why ComCatÒ performed better than others.

For the increase in yield of ComCat ${ }^{\circledR}+$ manure treatment, it seems that the ComCat ${ }^{\circledR}$

TABLE 4. The effects of ComCat ${ }^{\circledR}$, manure, and nitrogen and phosphorous fertilisation on the marketable, unmarketable, total fruit number and weight of fresh market tomato (Marglobe)

\begin{tabular}{|c|c|c|c|c|c|c|}
\hline \multirow[t]{2}{*}{ Treatments } & \multicolumn{3}{|c|}{ Number of fruit per plot } & \multicolumn{3}{|c|}{ Fruit yield ( $\mathrm{t} \mathrm{ha}{ }^{-1}$ ) } \\
\hline & M & UM & Total & M & UM & Total \\
\hline $\mathrm{CC}$ & $938.67^{\mathrm{a}}$ & $61.67^{c}$ & $1000.34^{a}$ & $55.00^{\mathrm{a}}$ & $3.52^{\mathrm{d}}$ & $58.53^{\mathrm{a}}$ \\
\hline M & $689.33^{b}$ & $58.33 c$ & $747.66^{\mathrm{b}}$ & $41.65^{b c}$ & $4.79^{b} \mathrm{C}$ & $46.44^{\mathrm{abc}}$ \\
\hline NP & $615.67 \mathrm{~b}$ & $122.00 \mathrm{a}$ & $737.67 \mathrm{~b}$ & $36.69 c$ & 6.13 & $42.82 \mathrm{bc}$ \\
\hline$C C+M$ & $987.33^{a}$ & $65.67^{c}$ & $1053.00^{\mathrm{a}}$ & $52.01^{a b}$ & $3.76^{c d}$ & $55.77^{a b}$ \\
\hline $\mathrm{CC}+\mathrm{NP}$ & $445.00^{c}$ & $95.33^{b}$ & $540.33^{c}$ & $13.74^{d}$ & $4.99^{a b}$ & $18.73^{\mathrm{d}}$ \\
\hline C & $623 .{ }^{30 \mathrm{~b}}$ & $69.00^{c}$ & $692^{b}$ & $33.48^{c}$ & $4.19 b^{c d}$ & $37.67^{c}$ \\
\hline Significance & * & * & * & * & * & * \\
\hline $\mathrm{SE}+$ & 31.268 & 6.9926 & 30.397 & 3.9781 & 0.3856 & 4.0848 \\
\hline
\end{tabular}

$\mathrm{M}=$ Marketable yield or number; $\mathrm{U}=$ unmarketable yield or number; $\mathrm{T}=$ Total yield or number; Means within the same column followed by a common letter are not significantly different at $\mathrm{P}<0.01$ (LSD); $\mathrm{CC}=\mathrm{ComCat} ; \mathrm{M}=$ Manure; $\mathrm{NP}=$ nitrogen and phosphorous. $\mathrm{C}+\mathrm{M}=\mathrm{ComCat}+$ manure, $\mathrm{C}+\mathrm{NP}=\mathrm{ComCat}+$ nitrogen and phosphorous, $\mathrm{C}=$ control 
enabled better nutrient uptake the earlier growth stage and slow release of nitrogen from manure that might have contributed to the nutrient demand of the plant in the later stage of growth.

The highest unmarketable fruit yield was obtained from NP while the least was from ComCat ${ }^{\circledR}$ treated tomatoes. The unmarketable tomato fruit yield obtained from manure treated tomatoes was significantly lower than NP treated tomato fruits. Most of the fruit grouped as unmarketable were characterised by features such as bird attack, crack, soft rot and irregular shape. Blossom end rot appeared due to preharvest ComCat ${ }^{\circledR}+$ NP fertiliser treatment. This could be due to the excess $\mathrm{N}$ that might have fostered $\mathrm{Ca}^{++}$deficiency, which is responsible for the cause of blossom end rot (Shaykkewich et al., 1971).

The difference in marketable fruit yields from manure and inorganic fertiliser was not significant ( $\mathrm{P}>0.05)$; however, higher yield was obtained from manure than inorganic fertiliser treated tomato plants. In support of this study, Cacek and Lagner (1986) reported the advantage of accruing from over-fertilisation by adding decomposed organic material. Application of manure and inorganic fertiliser did not show significant $(\mathrm{P}<0.05)$ variation in both total and marketable fruit yield compared to control. This is in agreement with the result of Lambeth (1958) and Wilcox (1962) as cited by Davies and Hobson (1971) that yield of tomatoes has not been affected by N. However, contrary to this result, Winsor et al., 1970 reported yield increase in tomato due to nitrogen application. Some of the possible reason for the comparable performance of control with fertiliser application under the present study could be attributed to the inherent fertility of the soil and uniform irrigation.

On the other hand, application of ComCat ${ }^{\circledR}$ + NP fertiliser depressed the performance of the crop, even when compared to the control treatment. It is reported that ComCat ${ }^{\circledR}$ is applied additional to normal fertiliser (Schnable et al., 2001). However, contrary to their findings, ComCat ${ }^{\circledR}+$ NP highly reduced yield in the present study. This could also be due to the cumulative effect of nitrogen in the soil and the additional $\mathrm{N}$ application, which leads to excessive vegetative growth. In this condition the plant may grow well, but be late yielding or low yielding because vegetative growth is favored over reproductive growth (Wudiri and Henderson, 1985).

In general, both ComCat ${ }^{\circledR}$ and ComCat ${ }^{\circledR}+$ manure treatments had an enhancing effect on the yield of tomatoes where $39.1 \%$ and $35.62 \%$ more marketable yield increase was shown than in the control tomatoes, respectively. Hüster (2001) reported yield increased due to ComCat ${ }^{\circledR}$ in cabbage, cauliflower, beetroot and other cereal crops (wheat and maize).

Application of manure resulted in 19.6\% increment in marketable yield while application of inorganic fertiliser resulted in only $8.74 \%$ increment when compared to control. Even though there has been much controversy over manure versus inorganic fertiliser on yield increment, in the present study, manure out performed by $10.86 \%$. However, the harvest ComCat ${ }^{\circledR}+$ NP treatment showed marketable yield reduction by $58.9 \%$ when compared to control.

The high performance of ComCat ${ }^{\circledR}$ over the other treatments in both total and marketable yield could be due to the larger and broader leaves produced by ComCat ${ }^{\circledR}$ and might have increased the photosynthetic efficiency. Similarly, the increase in plant height and primary lateral shoot number in ComCat ${ }^{\circledR}+\mathrm{NP}$ and NP fertilised tomato plants did not lead to increase in total and marketable yield. This might indicate that stimulation of early growth could compete with fruit set and development and is not desirable for obtaining acceptable yields. ComCat ${ }^{\circledR}$ does not have an early vegetative growth stimulating effect, as is well known for early nitrogen fertilisation (Hüster, 2001).

Quality at harvest. At harvest, the green mature ComCat ${ }^{\circledR}$ treated tomatoes contained significantly $(\mathrm{P}<0.01)$ higher TSS compared with $\mathrm{NP}$, ComCat ${ }^{\circledR}+\mathrm{NP}$ and ComCat ${ }^{\circledR}+$ manure treated tomato fruits. However, it did not show significant difference $(\mathrm{P}>0.01)$ when it is compared with the control and manure treated tomatoes. Seyoun (2002) reported that ComCat ${ }^{\circledR}$ increased the biosynthesis of polysaccharide carbohydrates while efficiently utilising free sugars for physiological processes during growth and development. ComCat ${ }^{\circledR}$ is also known to 
increase the chlorophyll content and hence increase the production of carbohydrate (Hüster, 2001).

At harvest, manure treatment showed increase in TSS content of tomatoes than NP treatment, not significant at $\mathrm{p}<0.01$ (Table 5). This increase in the TSS content of manure treated tomatoes could be due to higher photosynthetic efficiency by the relatively large and broader leaves and increase of fruit sink strength. This result contradicts with findings of Jeniffer (2003) who reported higher TSS concentration at harvest and after storage due to conventional fertiliser application in apple. However, this observation is in agreement with the findings of Raupp (1996) who reported the positive effect of manure on TSS content of vegetables. Mccollum et al. (2004) found slight difference in soluble solids or acidity between conventional and organically grown fruit. Among the preharvest treatments, only ComCat ${ }^{\circledR}+\mathrm{NP}$ treatment significantly $(\mathrm{P}<0.01)$ decreased the TSS content of tomato at harvest compared with the control. The rate of assimilate export from leaves and rate of import by fruit might be lower as vegetative growth was favoured against reproductive growth in this treatment.

Preharvest treatment significantly $(\mathrm{p}<0.01)$ reduced the $\mathrm{pH}$ value of tomato fruits (Table 5). Moreover, preharvest treatments significantly affected the TA of tomato fruits at harvest (Table
5). Significantly $(\mathrm{P}<0.01)$ higher titratable acid content of tomato fruit was found in NP, manure and ComCat ${ }^{\circledR}$ treated tomato fruits compared to ComCat ${ }^{\circledR}$ combined with the fertilisers and control tomatoes. The increase in TA of tomato where manure and NP fertiliser applied is in accordance with the result reported by Hedge and Srinivas (1990) in that acidity increased with increasing fertiliser application. The high TA of ComCat ${ }^{\circledR}$ treated tomato than in control tomatoes is in agreement with report of Seyoum (2002). ComCat ${ }^{\circledR}+$ NP treated tomato also showed significantly $(\mathrm{P}<0.01)$ higher TA than ion the controls, however, ComCat ${ }^{\circledR}+$ manure treated tomato had statistically similar TA content with that of ComCat ${ }^{\circledR}+\mathrm{NP}$ and control. The least TA value was observed in the control tomatoes and ComCat ${ }^{\circledR}+$ manure treated tomatoes. At harvest, the application of manure had a positive effect on the accumulation of AA content in tomatoes. Raupp (1996) indicated the positive effect of manure on the content of dry matter, sugar and AA in vegetables. Earlier studies by Cacek and Lagner (1986) also showed the positive effect of organic fertiliser on the nutritional value of vegetables. ComCat ${ }^{\circledR}+\mathrm{NP}$ treatment significantly $(\mathrm{P}<0.01)$ lowered AA content of tomato fruits compared to the control. The lower AA content in the preharvest NP and ComCat ${ }^{\circledR}+\mathrm{NP}$ and ComCat ${ }^{\circledR}+\mathrm{NP}$ treatments could be due to the effect of $\mathrm{N}$ fetilization.

TABLE 5. Effect of preharvest treatments on the chemical quality attributes of green manure tomato fruits

\begin{tabular}{|c|c|c|c|c|c|c|}
\hline \multirow[t]{2}{*}{ Treatment } & \multicolumn{6}{|c|}{ Chemical composition* } \\
\hline & TSS & $\mathrm{pH}$ & $\mathrm{TA}$ & AA & $\mathrm{RS}(\mathrm{g} / 100 \mathrm{~g} F W)$ & Tsugar (g/100 g FW) \\
\hline $\mathrm{CC}$ & $4.867^{\mathrm{a}}$ & $3.838^{c}$ & $1.254^{\mathrm{a}}$ & $11.72 b^{c}$ & $0.6912^{\mathrm{bc}}$ & $1.841^{\mathrm{c}}$ \\
\hline M & $4.533^{\mathrm{ab}}$ & $3.981^{b}$ & $1.209^{a}$ & $14.92^{\mathrm{a}}$ & $0.7094^{b}$ & $2.027^{b}$ \\
\hline NP & $4.333^{\mathrm{bc}}$ & $4.017^{\mathrm{b}}$ & $1.376^{\mathrm{a}}$ & $12.97^{b}$ & $0.7732^{\mathrm{ab}}$ & $1.633^{d}$ \\
\hline$C C+M$ & $4.333^{\mathrm{bc}}$ & $3.929^{\text {bc }}$ & $0.4463^{b c}$ & $12.36^{b}$ & $0.6212^{\text {cd }}$ & $1.125^{e}$ \\
\hline$C C+N P$ & $4.067^{c}$ & $4.038^{b}$ & $0.5887^{\mathrm{b}}$ & $10.88^{c}$ & $0.5546^{d}$ & $1.156^{\mathrm{e}}$ \\
\hline C & $4.667^{a b}$ & $4.213^{\mathrm{a}}$ & $0.37^{c}$ & $13.00 b$ & $0.7998^{\mathrm{a}}$ & $2.623^{a}$ \\
\hline Significance & $\star *$ & $\star *$ & $\star *$ & ** & ** & ** \\
\hline $\mathrm{SE} \pm$ & 0.063 & 0.005 & 0.007 & 0.561 & 0.0211 & 0.005 \\
\hline
\end{tabular}

${ }^{*}$ TSS = Total soluble solids; AA = Ascorbic acid; TA = Titratable acidity 
Likewise, Lisiewska and Kmiecik (1996) reported a decrease in AA content of fruits and vegetable with increasing amounts of nitrogen fertiliser.

\section{CONCLUSION}

Field study on the effect of preharvest treatment of ComCat ${ }^{\circledR}$, ComCat ${ }^{\circledR}+$ manure, ComCat ${ }^{\circledR}+$ $\mathrm{NP}, \mathrm{NP}$ and manure were conducted on marglobe tomato culture. Vigorous growth was observed in ComCat ${ }^{\circledR}$ treated tomato plants. Seedling established earlier in ComCat ${ }^{\circledR}$, ComCat ${ }^{\circledR}+\mathrm{NP}$ and NP treated tomato plants whereas establishment was delayed in manure, ComCat ${ }^{\circledR}$ + manure and control tomato plants. Highest yield was obtained from foliar application of ComCat ${ }^{\circledR}$ and ComCat ${ }^{\circledR}+$ manure treatments. Supplementing the recommended NP fertilisers withComCat ${ }^{\circledR}$ reduced both marketable and total yield. Supplementing ComCat ${ }^{\circledR}$ with manure fertiliser slightly improved yield over ComCat ${ }^{\circledR}$ alone. In general, both ComCat ${ }^{\circledR}$ and ComCat $\AA$ + manure treatments had an enhancing effect on the yield of tomatoes where $39.1 \%$ and $35.62 \%$ yield increase was shown than in the control tomatoes, respectively. The differences in marketable fruit yields from manure and inorganic fertiliser was not significant ( $p<0.05$ ); however, higher yield was obtained from manure than inorganic fertiliser treated tomato plants. Application of manure resulted in 206\% increment in marketable yield while application of inorganic fertiliser resulted in only $9 \%$ increment compared to the control. Manure outperformed by about $11 \%$ compared to inorganic fertiliser. In summary, the yield of tomatoes was improved under semiarid conditions of the experimental area through the use of preharvest ComCat ${ }^{\circledR}$ and ComCat ${ }^{\circledR}+$ manure treatment.

The preharvest treatments significantly influenced the quality of tomatoes at harvest. ComCat ${ }^{\circledR}$ treated tomato fruits had lower $\mathrm{pH}$, AA, reducing sugar and total sugar, and higher TA and TSS content. ComCat ${ }^{\circledR}$ treatment combined with manure and NP fertilisers has shown lower pH, TSS, TA, AA, RS and TS. Manure treated tomato fruits had higehr TSS, TA, $\mathrm{AA}<\mathrm{TS}$ and RS. NP fertiliser application resulted in higher TA.

\section{REFERENCES}

Aoca 1970. Official methods of Analysis $12^{\text {th }} \mathrm{edn}$. Association of Agricultural Chemist Washington, DC.

Belay, A. 2002. Factors influencing loan repayment performance of rural women in eastern Ethiopia. The case of Dire Dawa Area. An MSc Thesis presented to the School of Graduate Studies of Alemanya University. 102p.

Brecht, J.K., Bisogini, L. and Mungek, H.M. 1976. Effect of fruit position, stage of ripening and growth habit on chemical composition of fresh tomatoes. J. Amer. Soc. Hort. Sci. 41: 945948.

Cacek, T. and Lagner, L.L. 1986. The economic implications of organic farming. Am. J. Altern. Agric. 1:25-29.

Dieleman, J.A. and Heuvelink, E. 1992. Factors affecting the number of leaves preceding the first inflorescence in the tomato. J. Hort. Sci. 67:1-10.

Fischer, A.D.A. and Richter, C.H. 1986. Influence of organic and mineral fertilisers on yield and quality of potatoes. In: Proceedings of the Fifth IFOAM Conferences, Germany. 75p.

Hobson, G.E. 1964. Polygalacturonase in normal and abnormal tomato fruit. J. Biochem. 92: 324-332.

Hader, Y. 1986. The role of organic matter in the introduction of biofertilisers and biocontrol agents to soil. Pp 169-180. In; Chen, Y., Y. Avnimelech, eds. The Role of Organic Matter in Modern Agriculture. Boston: Martinus Nijhoff Publishers.

Hedge, D.M. and Srinivas, K. 1990. Effect of irrigation and nitrogen on yield, nutrient uptake and water use of tomato. Gartenbauwissenschaft 55 (4): 173-177.

Hüster, T. 2001. ComCatÒ. Personal Communication. Institute of Molecular Physiology and Biotechnology of Plants University of Bonn. AgraFurum, Germany.

Jennifer, 2003. Postharvest quality and sensory attributes of organically grown apples. Ministry of Agri. And Food. Ontario, Canada. www.ysiwyg:// 
Lisiewaska, Z. and Kmiecik, W. 1996. Effect of level of nitrogen fertiliser, processing conditions and period of storage for frozen broccoli and cauliflower on vitamin C retention. Food Chem. 57:267-270.

Mccollum, T.G., Chellemi, D.O., Rosskopf, E.N., Church, G.T. and Plotto, A. 2004. Postharvest quality of tomatoes produced in organic and conventional production systems. American Society of Horticulture Science Meeting. Horti. Sci. 40(4):959.

Raupp, J. 1996. Quality of plant products grown with manure fertilisation. Pp 44-48. In comparison of food quality organically versus conventionally grown vegetables www.eap.mcgill.ca/publications/EAP 38.htm,

Schnabl, H., Roth, U. and Friebe. A. 2001. Brassinosteroids-induced stress tolerances of plants. Recent Res. Devel. Phytechem. 5: 169183.

Shaykewich, C.F, Yamaguhi, M. and Campbell, J.D. 1971. Nutrition and blossomed rot of tomatoes as influenced by soil water regime. Can. J. Plant Sci 51:505-511.
Seyoun, T. 2002. The improvement of the shelf life of vegetables through pre and postharvest treatment. Ph.D. Dissertation presented to the University of Free State. South Africa. pp. 270.

Wudiri, B.B. and Henderson, D.W. 1985. Effect of water stress on flowering and fruit set in processing tomatoes. Scie. Horti. 27: 189198.

Winsor, G.W. 1970. A long-term factorial study of the nutrition of greenhouse tomatoes, fertilisation of protected crops. Proceedings of the $6^{\text {th }}$ Colloquium of the International Potash Institute, Florence 1968, International Potash Institue, Berne, Switzerland. Pp. 269281.

Pretorious J.C., Van der Watt E. and Buitendag, R.A. 2003. Natural products from plants. Department of Soi, Crop and Climate Sciences, University of the Free State, P. O. Box 339, Bloemfontein. 